Check for updates

Cite this: RSC Adv., 2017, 7, 45260

Received 11th August 2017

Accepted 13th September 2017

DOI: 10.1039/c7ra08872h

rsc.li/rsc-advances

\section{The modular synthesis of multivalent functionalised glycodendrons for the detection of lectins including DC-SIGN $\uparrow$}

\author{
Stefan Munneke, ${ }^{a}$ Kristel Kodar, ${ }^{a}$ Gavin F. Painter, (D) ${ }^{\text {bc }}$ Bridget L. Stocker ${ }^{\star a b}$ \\ and Mattie S. M. Timmer (D) *ab
}

\begin{abstract}
Glycodendrons are excellent tools for the biological evaluation of lectins. Herein, we present the expedient and efficient synthesis of a versatile second generation dendron scaffold using double exponential growth methodology. The dendron scaffold can be rapidly functionalised, as illustrated by the conjugation of the dendron scaffold to biotin or a fluorescent probe, followed by oxyamine glycan conjugation to the glycan of choice. The use of a fluorescent Lewis ${ }^{x}$ glycodendron for the detection of the C-type lectin DC-SIGN on macrophages is then demonstrated.
\end{abstract}

\section{Introduction}

Glycoconjugates, such as glycolipids and glycoproteins, are essential to all forms of life. These fundamental cellular constituents are involved in a variety of biological processes, such as host cell recognition, inflammation, cell signalling and proliferation, ${ }^{1,2}$ with the carbohydrate portion of the glycoconjugate often interacting with lectins (carbohydrate binding proteins) that are expressed on the surface of cells. Lectins, however, generally have a weak affinity for their carbohydrate ligands and therefore require multivalent interactions in order to induce a biological response. ${ }^{3}$ Thus, to study carbohydratelectin binding, the glycan epitope is typically conjugated to a substrate that allows for multivalent presentation. ${ }^{4}$ To this end, dendrimers and dendrons have both been used for the multivalent presentation of glycans. One advantage of the use of a glycodendron is that its core can be functionalised with reporter groups (e.g., fluorescent groups, biotin) or with toxins, which can allow for the detection, isolation or elimination of cells that expresses the target lectin.

Given the application of glycodendrons for the study of carbohydrate-lectin interactions, we became interested in developing a highly efficient synthesis of a dendron scaffold that could be readily functionalised with the molecular probe of choice and with glycans using our recently developed oxyamine

${ }^{a}$ School of Chemical and Physical Sciences, Victoria University of Wellington, P.O. Box 600, Wellington, New Zealand. E-mail: mattie.timmer@vuw.ac.nz

${ }^{b}$ Centre for Biodiscovery, Victoria University of Wellington, P.O. Box 600, Wellington, New Zealand

${ }^{c}$ Ferrier Research Institute, Victoria University of Wellington, P.O. Box 600, Wellington, New Zealand

$\dagger$ Electronic supplementary information (ESI) available. See DOI: $10.1039 / \mathrm{c} 7 \mathrm{ra} 08872 \mathrm{~h}$ linker methodology. ${ }^{5,6}$ This oxyamine methodology is not only highly efficient and allows for the conjugation of naturally occurring (isolated) glycans, but it also leads to the formation of $\beta$-linked GlcNAc residues, which are commonly found conjugated to proteins in the form of $N$-glycans. ${ }^{7}$ To this end, we proposed that the target glycodendron 1 could be prepared via peptide coupling of the carboxy-functionalised dendron 2 to the amine-functionalised neoglycoside prepared via conjugation of glycan 3 to 3-(methoxyamino)propan-1-amine (4) (Scheme 1). The dendron scaffold 2 would in turn contain the molecular probe of choice. The oxyamine ligation methodology has not been used for the conjugation of multiple copies of a glycan to a molecular scaffold, so we first envisioned synthesizing a glycodendron containing GlcNAc as proof-of-concept, before extending our methodology to include the glycan Lewis ${ }^{\mathrm{X}}$. Lewis ${ }^{\mathrm{X}}$ is a ligand for the C-type lectin DC-SIGN [also known as Cluster of Differentiation 209 (CD209)], ${ }^{8}$ which is expressed on the cell wall of several cells types, ${ }^{9-11}$ with alternatively-activated ('M2like') macrophages expressing higher levels of DC-SIGN compared to their classically-activated ('M1-like') counterparts. ${ }^{12}$ Moreover, DC-SIGN can be used by the human immunodeficiency virus (HIV), Ebola, hepatitis C, and non-viral pathogens, such as Mycobacterium tuberculosis, to infect host cells. ${ }^{13,14}$ Accordingly, DC-SIGN is an attractive target for glycodendron/glycodendrimer therapeutics. ${ }^{15-18}$

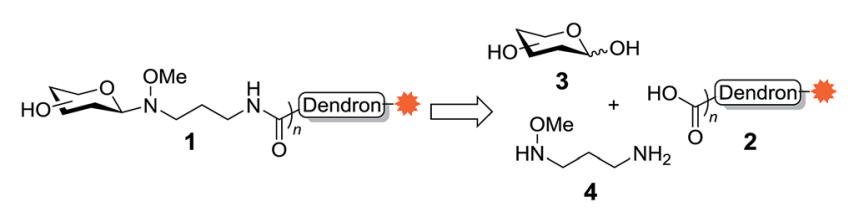

Scheme 1 Assembly of glycodendrons using an amine-functionalised oxyamine linker. 


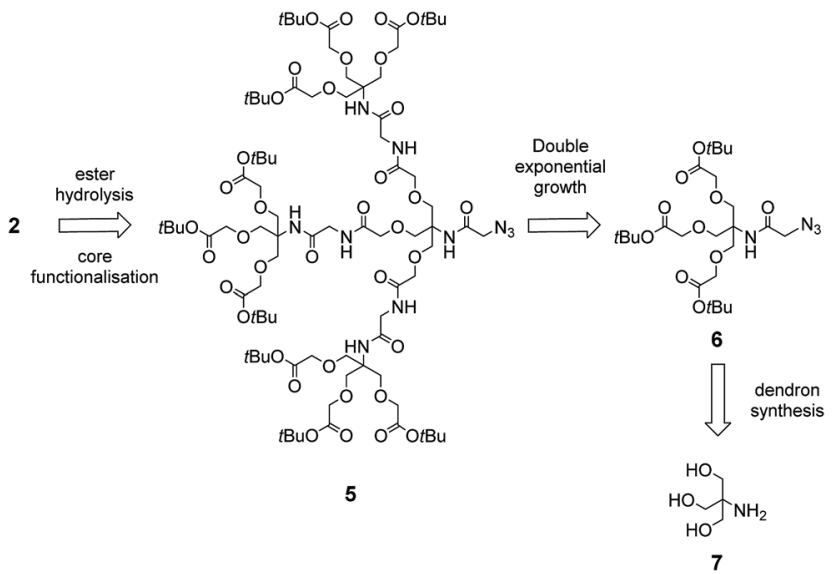

Scheme 2 Retrosynthesis of the dendron scaffold

To synthesise the dendron scaffold 2 we proposed a double exponential growth strategy. ${ }^{19}$ For the double exponential growth methodology, a protected first-generation dendron is synthesised and then converted to a second-generation dendron in a parallel synthesis. This strategy has merit since it allows for the easy purification of the first-generation dendron, minimises the number of steps to assemble larger dendrons, and therefore facilitates the rapid assembly of second-, thirdand fourth-generation dendrons. ${ }^{20}$ Depending on the functional groups at the periphery of the dendron, a variety of strategies can then be employed for the conjugation of glycans, including copper-catalysed 'click' reactions, ${ }^{21}$ and reductive amination. ${ }^{22}$ We envisioned that dendron 2 could be obtained from precursor $\mathbf{5}$ via Staudinger reduction of the azide in $\mathbf{5}$ to an amine and subsequent peptide coupling with a probe equipped with a carboxylic acid, followed by hydrolysis of the terminal $t$-butyl esters groups (Scheme 2). The protected dendron 5 could in turn be prepared from the first generation dendron 6 via double exponential growth methodology. Finally, it was envisioned that dendron 6 could be synthesised in two steps from the highly versatile branching unit tris(hydroxymethyl)aminomethane (TRIS, 7) ${ }^{23}$ using amide formation and tri-O-alkylation with tert-butyl bromoacetate.

\section{Results}

The synthesis of the first generation dendron commenced with azide substitution of bromoacetic acid (8) to give azide derivative 9, which in turn was converted into the activated ester $10 \mathrm{via}$ a DCC-mediated coupling with $N$-hydroxysuccinimide (Scheme $3)$. Conjugation of $\mathbf{1 0}$ with excess TRIS (7) then gave triol 11 in $80 \%$ yield over three steps. With the triol in hand, alkylation using $\mathrm{NaH}$ and tert-butyl bromoacetate in DMF then gave the first generation dendron 6. Here it was determined that the rapid addition of $\mathrm{NaH}$ to a mixture of triol $\mathbf{1 1}$ and tert-butyl bromoacetate in DMF : toluene $(1: 1)$ at room temperature minimised the formation of partially alkylated intermediates and afforded dendron 6 in $47 \%$ yield. While this alkylation yield may appear modest, the remaining steps for the synthesis of our

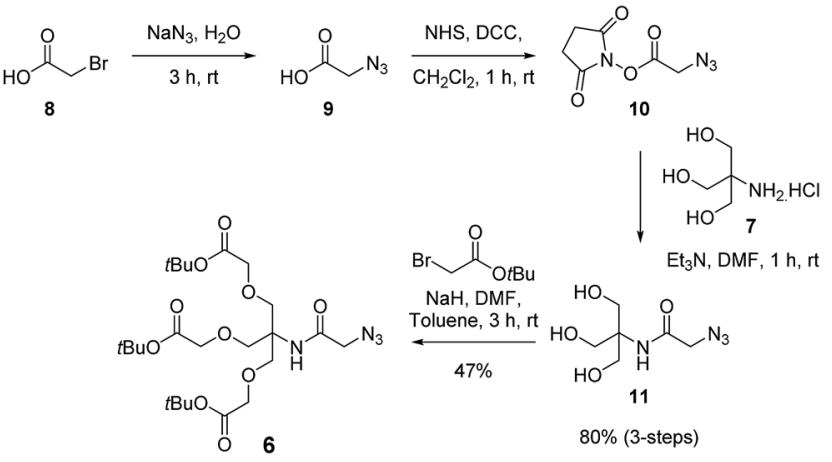

Scheme 3 Synthesis of the first generation dendron 8 .

target dendron scaffold $\mathbf{5}$ are very efficient (vide infra). Moreover, similar yields have been reported for the tri-O-alkylation of TRIS using analogous substrates, as illustrated by Dupuy et al. who reported a 53\% yield for the tri-O-alkyl-ation of $\mathrm{N}, \mathrm{N}$ diphenyl-TRIS with tert-butyl bromoacetate using a two-phase system,${ }^{24}$ while Newkome et al. prepared a tri-acid functionalised dendron core in two-steps via the Michael addition of TRIS to acrylonitrile followed by nitrile hydrolysis to give the ethyl esters in $54 \%$ over two steps. ${ }^{25}$ It should also be noted that our route was readily amenable to synthesis on the gram scale, and following purification of dendron 6 via silica gel chromatography followed by reverse phase $\left(\mathrm{C}_{18}\right.$ beads) chromatography, the first-generation dendron $\mathbf{6}$ was obtained in excellent purity.

With the first generation dendron in hand, the synthesis of the second-generation dendron was then explored using the double exponential growth approach. Accordingly, the first generation dendron 6 was divided into two batches for conversion into the two reactive substrates (Scheme 4). Deprotection of the tert-butyl esters of 6 via the agency of TFA/ $\mathrm{CH}_{2} \mathrm{Cl}_{2}$ $(1 / 1, v / v)$ gave the tri-valent acid 12 in quantitative yield, while azide reduction of $\mathbf{6}$, using RANEY® nickel mediated hydrogenation, afforded primary amine 13, again in quantitative yield. Next, $\quad N, N, N^{\prime}, N^{\prime}$-tetramethyl-O-(1H-benzotriazol-1-yl)uronium

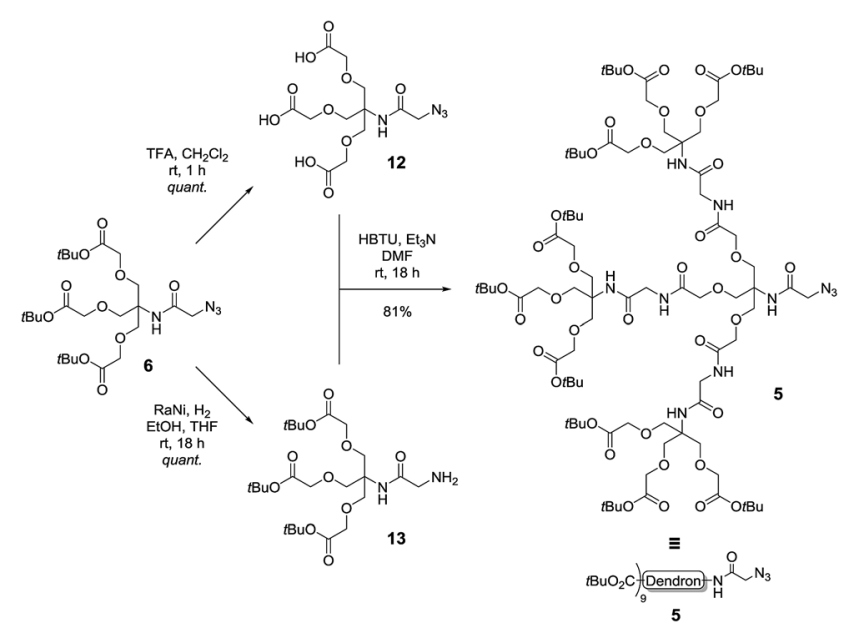

Scheme 4 Synthesis of second generation dendron 5 using a double exponential growth coupling strategy. 
hexafluorophosphate (HBTU)-mediated coupling of tri-acid 12 with amine 13 was undertaken to give the second-generation dendron 5 in $81 \%$ yield and in $>95 \%$ purity following silica gel chromatography followed by reverse phase $\left(\mathrm{C}_{18}\right.$ beads) chromatography. Again, these reactions could be performed on the gram scale.

To demonstrate the versatility of our synthetic methodology, we then sought to functionalise the dendron scaffold 5 with either biotin or a fluorescent group. First, proof-of-concept was established via the synthesis of a second-generation biotinfunctionalised dendron scaffold containing GlcNAc (Scheme 5). To this end, the azide in dendron 5 was converted into an amide via RANEY® nickel hydrogenation and the crude product coupled to D-biotin using an HBTU-mediated peptide ligation to give the biotinylated dendron $\mathbf{1 4}$ in $95 \%$ yield over two steps (Scheme 5). Removal of the tert-butyl esters using TFA in $\mathrm{CH}_{2} \mathrm{Cl}_{2}$ then occurred smoothly to afford carboxy dendron 15 in excellent yield, which was subsequently conjugated to oxyamine glycoside 16, itself prepared in $81 \%$ yield via the conjugation of GlcNAc to 3-(methoxyamino)propanyl-amine hydrochloride 4 according to previously published procedures. ${ }^{5}$ To facilitate the conjugation, excess oxyamine-functionalised glycan 16 ( 2 equiv. per carboxyl group) was used and the reaction mixture was stirred at room temperature overnight. Dialysis (cellulose ester dialysis membrane, 500 Da molecular weight cut-off) for 48 hours with a $0.1 \mathrm{M} \mathrm{Na}_{2} \mathrm{HPO}_{4}$ buffer at $\mathrm{pH} 7.5$ to prevent oxyamine linker hydrolysis ${ }^{26}$ followed by lyophilisation and reverse phase chromatography $\left(\mathrm{C}_{8}\right)$ then gave the biotinlyated glycodendron 17 in very good yield $(72 \%)$.

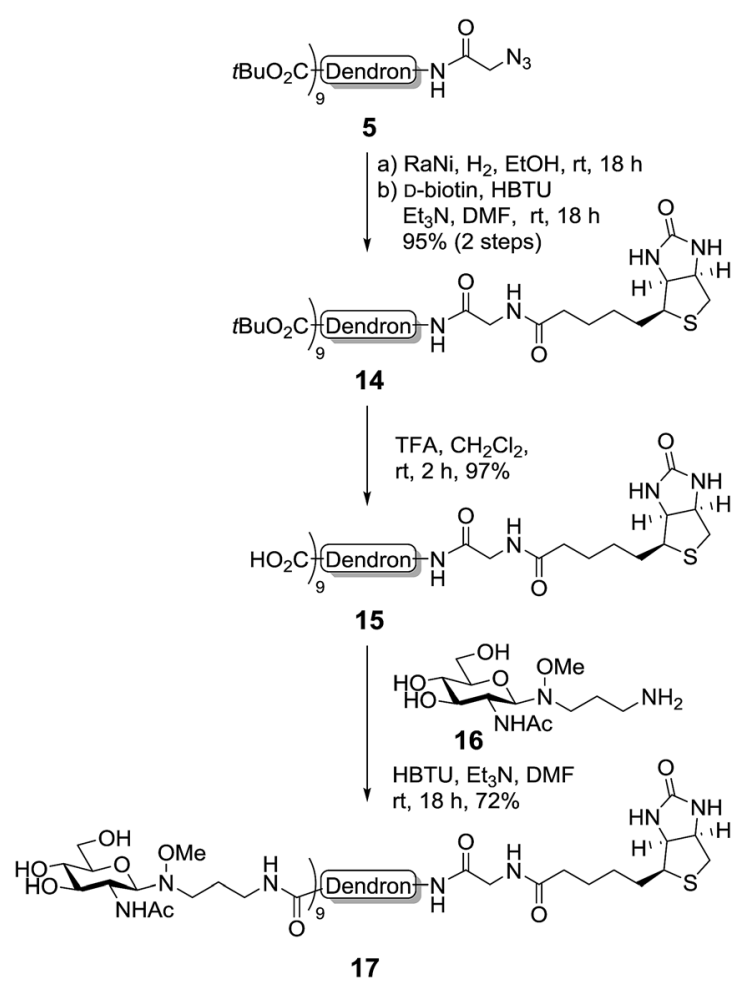

Scheme 5 Functionalisation of the second-generation dendron with biotin and GlcNAc.
To synthesise the Lewis ${ }^{\mathrm{X}}$ glycodendron, a similar reaction route to that employed for the biotinylation of the dendrimer core was undertaken. Accordingly, the azide-group in the tertbutyl ester-functionalised dendron $\mathbf{5}$ was first reduced to the corresponding amine and then coupled to fluorescein isothiocyanate (FITC) to yield fluorescein derivative $\mathbf{1 8}$ in good yield $(71 \%, 2$ steps, Scheme 6). Treatment of 18 with TFA however, resulted in the Edman degradation ${ }^{27}$ products 19 and 20. To prevent this reaction, the core dendron 5 was first converted into the corresponding amine via Staudinger reduction and the tert-butyl esters were then removed via treatment with TFA to give the amine-functionalised carboxy dendron 21 in excellent yield (99\%, 2 steps). Next, conjugation with FITC under basic conditions ( $\mathrm{NEt}_{3}$ in DMF) gave the target fluorescent dendron 22 , also in very good $(74 \%)$ yield. The fluorescent dendron was initially obtained as the triethylamine salt after size exclusion chromatography, however, as this salt hampered ligation to the neoglycoconjugates, ion exchange (Dowex- $\mathrm{H}^{+}$) was performed to obtain the dendron as the nona-valent acid.

For the assembly of the target Lewis ${ }^{\mathrm{x}}$ glycodendron, Lewis ${ }^{\mathrm{X}}$ $(23)^{28}$ was condensed with amine-functionalised oxyamine linker $\mathbf{4}^{10}$ (Scheme 7). When the reaction was performed at room temperature, only a small amount of glycoconjugate was observed, however, heating the reaction at $40{ }^{\circ} \mathrm{C}$ for 36 hours saw complete conversion to the desired oxyamine-linked $\mathrm{N}$-glycan. Purification by size exclusion chromatography (BioGel P2) then allowed for the isolation of the target oxyamine-linked glycan as the ammonium formate salt. As the presence of this salt could lead to the formation of formamide by-products in the subsequent peptide coupling reaction, the oxyamine-linked glycan was treated with ion exchange resin $\left(\right.$ Dowex $\left.\mathrm{OH}^{-}\right)$to give the free amine 24 in excellent yield (88\%). Next, conjugation with the FITC-labelled second-generation dendron 22 was performed using an HBTU-mediated peptide coupling reaction. Here, the order of addition of reagents was found to be important with the fluorescent dendron 22 being dissolved in freshly distilled DMF and then added to the Lewis ${ }^{\mathrm{x}}$ glycan $\mathbf{2 3}$ followed by the addition of HBTU and $\mathrm{Et}_{3} \mathrm{~N}$, as the glycan itself had poor solubility in DMF alone, though completely dissolved after the addition of HBTU

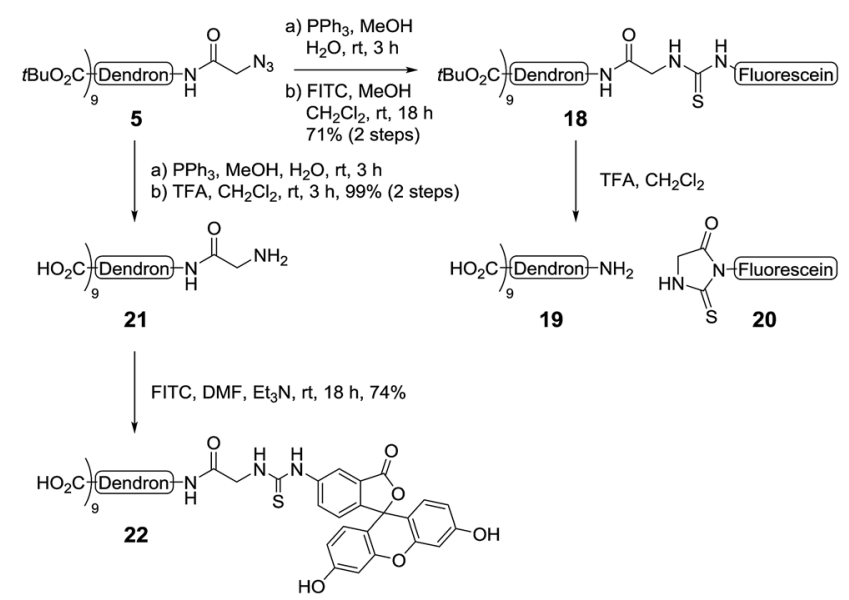

Scheme 6 Synthesis of fluorescent dendron. 


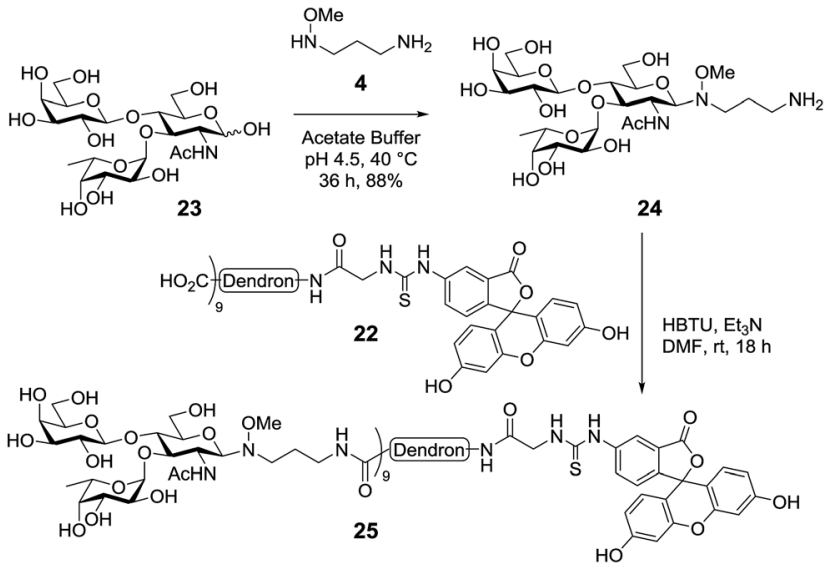

Scheme 7 Synthesis of the Lewis ${ }^{x}$ functionalized glycodendron via conjugation of Lewis ${ }^{x}$ to the fluorescein-derived second-generation dendron using the bi-functional oxyamine linker.

and $\mathrm{Et}_{3} \mathrm{~N}$. The reaction mixture was then stirred at room temperature overnight, upon which analysis by HRMS indicated that the desired nona-valent glycodendron was formed $(\mathrm{m} / \mathrm{z}$ for $\left[\mathrm{C}_{285} \mathrm{H}_{476} \mathrm{~N}_{36} \mathrm{O}_{168} \mathrm{~S}\right]^{4+}$ calcd: 1781.7393 , obsd: 1781.7380$)$. Purification of the glycodendron using size exclusion chromatography (Sephadex CM C-25, $0.1 \mathrm{M}$ aq. $\mathrm{NH}_{4} \mathrm{HCO}_{2}$ ) then allowed for the isolation of the fluorescent Lewis ${ }^{\mathrm{X}}$-functionalised glycodendron 25 in $51 \%$ yield.

To demonstrate the potential of glycodendron 25 as a chemical tool, we then assessed whether the glycodendron
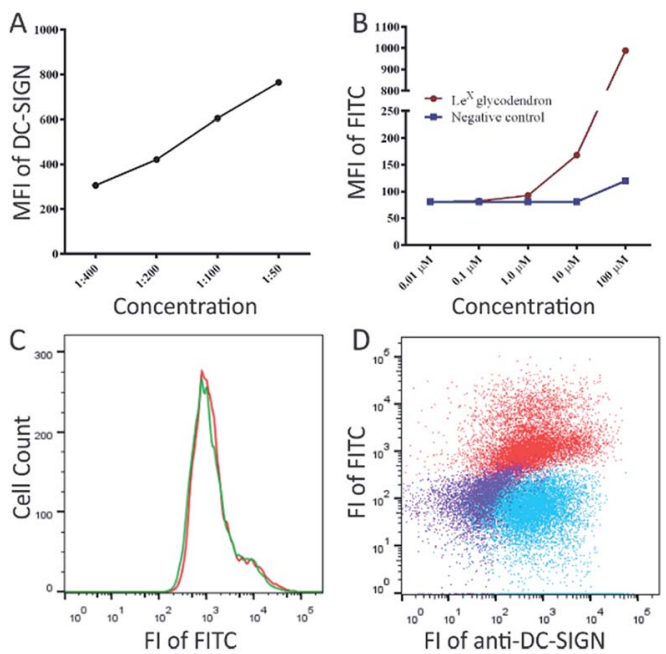

Fig. 1 The expression of DC-SIGN on THP-1 + PMA + IL-4 cells measured with (A) anti-DC-SIGN antibody and (B) unglycosylated dendron 21 (negative control) and the fluorescent Lewis ${ }^{x}$ glycodendron 27. (C) The co-staining with anti-DC-SIGN antibody does not affect glycodendron binding to THP-1 + PMA + IL-4 cells, single staining with $100 \mu \mathrm{M}$ glycodendron (green), co-staining of the antiDC-SIGN antibody with $100 \mu \mathrm{M}$ glycodendron (red); (D) the expression of DC-SIGN visualised with glycodendron and anti-DC-SIGN antibody on THP-1 + PMA + IL-4 cells, using single staining with the anti-DCSIGN antibody (blue), co-staining of the antibody with $100 \mu \mathrm{M}$ glycodendron (red) and unstained cells (purple). could be used to detect DC-SIGN on the human macrophage cell line THP-1. To this end, human THP-1 cells were converted to the M2-like phenotype via treatment with phorbol-12-myristate13-acetate (PMA) and interleukin (IL)-4, ${ }^{29}$ and the presence of DC-SIGN on the cells confirmed through use of an anti-DC-SIGN antibody (Fig. 1A). Glycodendron 25 was then made up in a stock-solution of $0.66 \mathrm{mg} \mathrm{mL}^{-1}(0.1 \mu \mathrm{M})$ and assessed for its ability to detect DC-SIGN on the THP-1 + PMA + IL-4 cells, with the unglycosylated dendron $\mathbf{2 2}$ being used as a negative control (Fig. 1B). As illustrated, both the anti-DC-SIGN antibody and the glycodendron 25 bound DC-SIGN in a concentration dependent manner (Fig. 1A and B). The unglycosylated dendron 22 did not show binding to the macrophages at low $\mu \mathrm{M}$ concentrations, with only the highest concentration tested $(100 \mu \mathrm{M})$ giving a slight increase in mean fluorescence due to non-specific binding. Next, co-staining of the glycodendron with the antiDC-SIGN antibody and 25 was conducted (Fig. 1C and D). Here, it is important to note that the co-staining with the antibody did not interfere with the glycan-mediated binding.

\section{Conclusions}

In conclusion, we have presented the design and synthesis of a dendron scaffold that can be readily functionalised at both its core and periphery. The synthesis of the second-generation dendron scaffold $\mathbf{5}$ was achieved in six linear steps and in an excellent overall yield of $30 \%$. Moreover, the ease of functionalisation of the dendron core was demonstrated via its rapid and efficient conversion to both biotinylated and fluorescently labelled derivatives. The use of oxyamine ligation methodology to efficiently conjugate multiple glycans to a dendron scaffold was presented via the conjugation of GlcNAc to the biotinylated dendron scaffold and the conjugation of Lewis ${ }^{\mathrm{x}}$ to a fluorescently labelled dendron scaffold, whereby the fluorescentlylabelled Lewis ${ }^{\mathrm{X}}$ glycodendron was used to detect DC-SIGN on macrophages. Given the efficiency and versatility of our procedures, we envision undertaking future carbohydrate-lectin binding studies employing glycodendron 25 and related glycodendrons in due course.

\section{Experimental}

\section{General procedures}

Prior to use, THF was distilled from sodium and benzophenone, $\mathrm{CH}_{2} \mathrm{Cl}_{2}$ was distilled from $\mathrm{P}_{2} \mathrm{O}_{5}$, DMF was distilled from $\mathrm{BaO}$, $\mathrm{Et}_{3} \mathrm{~N}$ was distilled from $\mathrm{KOH}$. All other reagents were used as received. 3-(Methoxyamino)propanyl-amine hydrochloride $\mathbf{4},{ }^{5}$ oxyamine-linked GlcNAc $16,{ }^{5}$ and Lewis ${ }^{\mathrm{X}}(\mathbf{2 3})^{27}$ were synthesised as previously described. All solvents were removed by evaporation under reduced pressure. Reactions were monitored by TLCanalysis on Macherey-Nagel silica gel coated plastic sheets $(0.20$ $\mathrm{mm}$, with fluorescent indicator $\mathrm{UV}_{254}$ ) with detection by UVabsorption (short wave UV - $254 \mathrm{~nm}$; long wave UV - $366 \mathrm{~nm}$ ), by dipping in $10 \% \mathrm{H}_{2} \mathrm{SO}_{4}$ in EtOH followed by charring at $\sim 150{ }^{\circ} \mathrm{C}$, by dipping in $\mathrm{I}_{2}$ in silica, or by dipping into a solution of ninhydrin in EtOH followed by charring at $\sim 150{ }^{\circ} \mathrm{C}$. Column chromatography was performed on Pure Science silica gel (40- 
63 micron). AccuBOND II ODS-C 18 (Agilent) was used for reverse phase chromatography. Infrared spectra were recorded as thin films using a Bruker Tensor 27 FTIR spectrometer equipped with an Attenuated Total Reflectance (ATR) sampling accessory and are reported in wave numbers $\left(\mathrm{cm}^{-1}\right)$. Nuclear magnetic resonance spectra were recorded at $20{ }^{\circ} \mathrm{C}$ in $\mathrm{D}_{2} \mathrm{O}, \mathrm{CD}_{3} \mathrm{OD}$, $\mathrm{CDCl}_{3}$, or pyridine- $\mathrm{d}_{5}$ using either a Varian INOVA operating at $500 \mathrm{MHz}$ or Varian VNMRS operating at $600 \mathrm{MHz}$. Chemical shifts are given in ppm $(\delta)$ relative to solvent residues. NMR peak assignments were made using COSY, HSQC and HMBC experiments.

$\mathrm{N}$-Hydroxysuccinimidyl azidoacetate (10). To a solution of bromoacetic acid 8 (15.1 g, $0.11 \mathrm{~mol})$ in water $(30 \mathrm{~mL}), \mathrm{NaN}_{3}$ $(30.0 \mathrm{~g}, 0.43 \mathrm{mmol}$ ) was added and the reaction mixture was stirred at r.t. for $3 \mathrm{~h}$. The reaction mixture was diluted with $6 \mathrm{M}$ aq. $\mathrm{HCl}(50 \mathrm{~mL})$ and extracted with $\mathrm{Et}_{2} \mathrm{O}(2 \times 100 \mathrm{~mL})$. The organic layers were dried with $\mathrm{MgSO}_{4}$, filtered and concentrated in vacuo, to give azide 9 as a colourless oil $(10.7 \mathrm{~g}, 0.11 \mathrm{mmol}$, 99\%). The crude reaction product was used in the esterification reaction without further purification. To a solution of crude 2azido acetic acid $9(9.70 \mathrm{~g}, 96.0 \mathrm{mmol})$ in dry $\mathrm{CH}_{2} \mathrm{Cl}_{2}(100 \mathrm{~mL})$, $N$-hydroxysuccinamide $(13.2 \mathrm{~g}, 115 \mathrm{mmol})$ and $N, N^{\prime}$-dicyclohexylcarbodiimide $(17.8 \mathrm{~mL}, 115 \mathrm{mmol})$ were added at $0{ }^{\circ} \mathrm{C}$ and the reaction mixture was stirred at r.t. for $18 \mathrm{~h}$. The reaction mixture was filtered and concentrated in vacuo. To the crude residue, EtOAc $(150 \mathrm{~mL})$ was added and the solids were removed by filtration and the mixture was concentrated in vacuo. The residue was purified by silica gel column chromatography (PE/ EtOAc, $75 / 25 \rightarrow 25 / 75, \mathrm{v} / \mathrm{v}$ ) and crystallised from $\mathrm{CH}_{2} \mathrm{Cl}_{2} / \mathrm{PE}$ to yield title compound $\mathbf{1 0}$ as a white solid (17.9 g, $90.2 \mathrm{mmol}$, 94\%). $R_{\mathrm{f}}=0.25$ (PE/EtOAc, $\left.1 / 1, \mathrm{v} / \mathrm{v}\right) ; \operatorname{mp~} 110-115{ }^{\circ} \mathrm{C}$; IR (film) 2995, 2935, 2110, 1818, 1781, 1727, 1428, 1416, 1369, 1278, 1199, $1087 \mathrm{~cm}^{-1} ;{ }^{1} \mathrm{H} \mathrm{NMR}\left(500 \mathrm{MHz}, \mathrm{CDCl}_{3}\right) \delta 4.24\left(\mathrm{~s}, 2 \mathrm{H}, \mathrm{CH}_{2}-\right.$ $\left.\mathrm{N}_{3}\right), 2.88\left(\mathrm{~s}, 4 \mathrm{H}, 2 \times \mathrm{CH}_{2} \mathrm{C}=\mathrm{O}\right) ;{ }^{13} \mathrm{C} \mathrm{NMR}\left(125 \mathrm{MHz}, \mathrm{CDCl}_{3}\right)$ $\delta 168.6(2 \times N-\mathrm{C}=\mathrm{O}), 164.3(\mathrm{O}-\mathrm{C}=\mathrm{O}), 48.1\left(\mathrm{CH}_{2}-\mathrm{N}_{3}\right), 25.7(2 \times$ $\left.\alpha \mathrm{CH}_{2}\right)$.

$\mathrm{N}$-Azidoacetyl-1,1,1-tris(hydroxymethyl)aminomethane (11). To a solution of succinimidyl ester $12(8.83 \mathrm{~g}, 44.6 \mathrm{mmol})$ in freshly distilled DMF (100 mL), TrisRIS(hydroxymethyl)aminomethane $7(26.9 \mathrm{~g}, 222 \mathrm{mmol})$ and $\mathrm{Et}_{3} \mathrm{~N}(0.6 \mathrm{~mL}, 4.5 \mathrm{mmol})$ were added and the reaction mixture was stirred at r.t. for $18 \mathrm{~h}$. The reaction mixture was concentrated in vacuo, then co-evaporated with $\mathrm{H}_{2} \mathrm{O}$ to remove traces of DMF. The residue was purified by silica gel column chromatography (dry-loading, PE : EtOAc, 50/ $50 \rightarrow 0 / 100, \mathrm{v} / \mathrm{v}$ ) yielded the title compound $\mathbf{1 1}$ as a white foam (7.84 g, $38.4 \mathrm{mmol}, 86 \%) . R_{\mathrm{f}}=0.50\left(\mathrm{CH}_{2} \mathrm{Cl}_{2} / \mathrm{EtOH} / \mathrm{MeOH} / \mathrm{NH}_{3}\right.$ (aq. 33\%), 5/2/2/1, v/v/v/v); IR (film) 3359, 2979, 2946, 2890, 2113, 1739, 1650, 1540, 1454, 1367, 1282, 1229, 1217, $1053 \mathrm{~cm}^{-1}$; ${ }^{1} \mathrm{H}$ NMR $\left(500 \mathrm{MHz}, \mathrm{D}_{2} \mathrm{O}\right) \delta 4.00\left(\mathrm{~s}, 2 \mathrm{H}, \mathrm{CH}_{2}-\mathrm{N}_{3}\right), 3.76$ $\left(\mathrm{s}, 6 \mathrm{H}, 3 \times \mathrm{CH}_{2}-\mathrm{O}\right) ;{ }^{13} \mathrm{C}$ NMR $\left(125 \mathrm{MHz}, \mathrm{D}_{2} \mathrm{O}\right) \delta 170.4(\mathrm{C}=\mathrm{O}$ amide), $62.1\left(\mathrm{C}_{\mathrm{q}}\right.$ tris $) 60.1\left(3 \times \mathrm{CH}_{2}-\mathrm{O}\right), 51.9\left(\mathrm{CH}_{2}-\mathrm{N}_{3}\right)$; HRMS(ESI) $m / z$ calcd for $\left[\mathrm{C}_{6} \mathrm{H}_{13} \mathrm{~N}_{4} \mathrm{O}_{4}\right]^{+}$: 205.0931, obsd: 205.0930 .

$\mathrm{N}$-Azidoacetyl-1,1,1-tris(tert-butyloxycarbonylmethyloxymethyl) aminomethane (6). To a solution of triol 11 (366 mg, $1.79 \mathrm{mmol}$ ) in DMF $(9 \mathrm{~mL})$ and toluene $(9 \mathrm{~mL})$, tert-butyl bromoacetate $(1.06$ $\mathrm{mL}, 7.16 \mathrm{mmol})$ and $\mathrm{NaH}(286 \mathrm{mg}, 7.16 \mathrm{mmol})$ were added and the reaction mixture was stirred at r.t. for $4 \mathrm{~h}$. The reaction mixture was quenched by the addition of ice water $(20 \mathrm{~mL})$ and was then extracted with $\mathrm{Et}_{2} \mathrm{O}(2 \times 100 \mathrm{~mL})$. The organic layers were dried with $\mathrm{MgSO}_{4}$, filtered and concentrated in vacuo. Purification by silica gel column chromatography (PE : EtOAc, 85/15 $\rightarrow$ 75/25, v/v) and reverse phase column chromatography $\left(\mathrm{C}_{18}, \mathrm{H}_{2} \mathrm{O} / \mathrm{MeOH}, 50\right.$ / $50 \rightarrow 20 / 80, \mathrm{v} / \mathrm{v}$ ) yielded tri-alkylated 6 as a white foam (464 mg, $0.85 \mathrm{mmol}, 47 \%$ ). $R_{\mathrm{f}}=0.44$ (PE/EtOAc, 70/30, v/v); IR (film) 3316, 2979, 2935, 2107, 1745, 1684, 1536, 1473, 1428, 1393, 1368, 1229, 1158, 1119, 1037, 971, 915, 845, 731, $647 \mathrm{~cm}^{-1}$; ${ }^{1} \mathrm{H}$ NMR $(500 \mathrm{MHz}$, $\left.\mathrm{CDCl}_{3}\right) \delta 7.86(\mathrm{~s}, 1 \mathrm{H}, \mathrm{NH}), 3.95\left(\mathrm{~s}, 6 \mathrm{H}, 3 \times \mathrm{CH}_{2} \mathrm{C}=\mathrm{O}\right), 3.92(\mathrm{~s}, 6 \mathrm{H}, 3$ $\left.\times \mathrm{CH}_{2}-\mathrm{O}\right), 3.85\left(\mathrm{~s}, 2 \mathrm{H}, \mathrm{CH}_{2}-\mathrm{N}_{3}\right), 1.45\left(\mathrm{~s}, 27 \mathrm{H}, \mathrm{CH}_{3} t \mathrm{Bu}\right) ;{ }^{13} \mathrm{C} \mathrm{NMR}$ $\left(125 \mathrm{MHz}, \mathrm{CDCl}_{3}\right) \delta 170.2(3 \times \mathrm{C}=\mathrm{O}$ ester $), 167.5(1 \times \mathrm{C}=\mathrm{O}$ amide), 82.0 $\left(3 \times \mathrm{C}_{\mathrm{q}} t \mathrm{Bu}\right), 70.1\left(3 \times \mathrm{CH}_{2}-\mathrm{O}\right), 68.9\left(3 \times \mathrm{CH}_{2} \mathrm{C}=\mathrm{O}\right)$, $60.1\left(\mathrm{C}_{\mathrm{q}}\right.$ tris), $52.9\left(\mathrm{CH}_{2}-\mathrm{N}_{3}\right), 28.2\left(9 \times \mathrm{CH}_{3} t \mathrm{Bu}\right) ; \mathrm{HRMS}(\mathrm{ESI}) \mathrm{m} / \mathrm{z}$ calcd for $\left[\mathrm{C}_{24} \mathrm{H}_{43} \mathrm{~N}_{4} \mathrm{O}_{10}\right]^{+}$: 547.2974, obsd: 547.2981.

$\mathrm{N}$-Azidoacetyl-1,1,1-tris(carboxymethyloxymethyl)aminomethane (12). To a solution of dendron 6 (508 $\mathrm{mg}, 0.93$ $\mathrm{mmol})$ in $\mathrm{CH}_{2} \mathrm{Cl}_{2}(5 \mathrm{~mL})$, freshly distilled trifluoroacetic acid $(5 \mathrm{~mL})$ was added and the reaction mixture was stirred at r.t. for $2 \mathrm{~h}$. The reaction mixture was then concentrated in vacuo and coevaporated with $\mathrm{CH}_{2} \mathrm{Cl}_{2}(10 \mathrm{~mL})$. The residue was purified by reverse phase column chromatography $\left(\mathrm{C}_{18}\right.$, $\left.\mathrm{H}_{2} \mathrm{O} / \mathrm{MeOH}, 100 / 0 \rightarrow 70 / 30, \mathrm{v} / \mathrm{v}\right)$ yielded acid 12 as a colourless oil. $R_{\mathrm{f}}=0.20\left(\mathrm{CH}_{2} \mathrm{Cl}_{2} / \mathrm{EtOH} / \mathrm{MeOH} / \mathrm{NH}_{3}\right.$ (aq. 33\%), 5/2/2/1, v/v/v/v); IR (film) 3418, 2930, 2114, 1727, 1661, 1547, 1427, 1249, $1121 \mathrm{~cm}^{-1}$; ${ }^{1} \mathrm{H}$ NMR (500 MHz, D $\left.\mathrm{D}_{2} \mathrm{O}\right) 4.20(\mathrm{~s}$, $\left.6 \mathrm{H}, 3 \times \mathrm{CH}_{2} \mathrm{C}=\mathrm{O}\right), 3.98\left(\mathrm{~s}, 6 \mathrm{H}, 3 \times \mathrm{CH}_{2}-\mathrm{O}\right), 3.90(\mathrm{~s}, 2 \mathrm{H}$, $\left.\mathrm{CH}_{2}-\mathrm{N}_{3}\right) ;{ }^{13} \mathrm{C}$ NMR $\left(125 \mathrm{MHz}, \mathrm{CDCl}_{3}\right) \delta 174.3(3 \times \mathrm{C}=\mathrm{O})$, $170.2(1 \times \mathrm{C}=$ O amide $), 69.6\left(3 \times \mathrm{CH}_{2}-\mathrm{O}\right), 68.1\left(3 \times \mathrm{CH}_{2} \mathrm{C}=\right.$ O), $59.9\left(\mathrm{C}_{\mathrm{q}}\right.$ tris), $52.0\left(\mathrm{CH}_{2}-\mathrm{N}_{3}\right)$; HRMS(ESI) $\mathrm{m} / \mathrm{z}$ calcd for $\left[\mathrm{C}_{12} \mathrm{H}_{19} \mathrm{~N}_{4} \mathrm{O}_{10} \mathrm{Na}\right]^{+}$: 401.0915 , obsd: 401.0920 .

$\mathrm{N}$-Glycyl-1,1,1-tris(tert-butyloxycarbonylmethyloxymethyl)aminomethane (13). To a solution of dendron $6(220 \mathrm{mg}$, $0.40 \mathrm{mmol})$ in ethanol $(1 \mathrm{~mL})$ and THF $(1 \mathrm{~mL})$, activated RANEY® nickel $(120 \mathrm{mg})$ was added and hydrogen gas was then bubbled through the reaction mixture at r.t. for $18 \mathrm{~h}$. The reaction mixture was filtered, washed with sat. $\mathrm{NaCl}$ (aq.) $(50 \mathrm{~mL})$ containing $1 \mathrm{M} \mathrm{NaOH}(1 \mathrm{~mL})$, extracted with $\mathrm{CH}_{2} \mathrm{Cl}_{2}$ $(2 \times 50 \mathrm{~mL})$ and the combined organic layers were dried, filtered and concentrated in vacuo. The residue was purified by silica gel column chromatography (EtOAc/MeOH, 100/0 $\rightarrow$ $85 / 15, \mathrm{v} / \mathrm{v})$ yielded amine 6 as a colourless oil $(207 \mathrm{mg}$, $0.40 \mathrm{mmol}, 99 \%) . R_{\mathrm{f}}=0.09$ (EtOAc/MeOH, 90/10, v/v); IR (film) 3336, 2978, 3933, 1745, 1674, 1520, 1368, 1300, 1229, 1159, 1121, 1044, $847 \mathrm{~cm}^{-1} ;{ }^{1} \mathrm{H}$ NMR (500 MHz, $\left.\mathrm{CDCl}_{3}\right) \delta 7.82$ $(\mathrm{s}, 1 \mathrm{H}, \mathrm{NH}), 3.92\left(\mathrm{~s}, 6 \mathrm{H}, 3 \times \mathrm{CH}_{2} \mathrm{C}=\mathrm{O}\right), 3.88\left(\mathrm{~s}, 6 \mathrm{H}, 3 \times \mathrm{CH}_{2}-\right.$ O), $3.30\left(\mathrm{~s}, 2 \mathrm{H}, \mathrm{CH}_{2}-\mathrm{NH}_{2}\right), 2.07$ (bs, $\left.2 \mathrm{H}, \mathrm{NH}_{2}\right) 1.42(\mathrm{~s}, 27 \mathrm{H}, 9 \times$ $\left.\mathrm{CH}_{3} t \mathrm{Bu}\right) ;{ }^{13} \mathrm{C} \mathrm{NMR}\left(125 \mathrm{MHz}, \mathrm{CDCl}_{3}\right) \delta 173.2(1 \times \mathrm{C}=\mathrm{O}$ amide $), 170.3(3 \times \mathrm{C}=\mathrm{O}$ ester $), 81.8\left(3 \times \mathrm{C}_{\mathrm{q}} t \mathrm{Bu}\right), 70.2(3 \times$ $\left.\mathrm{CH}_{2}-\mathrm{O}\right), 69.0\left(3 \times \mathrm{CH}_{2} \mathrm{C}=\mathrm{O}\right), 59.5\left(\mathrm{C}_{\mathrm{q}}\right.$ tris $), 45.6\left(\mathrm{CH}_{2}-\mathrm{NH}_{2}\right)$, $28.2\left(9 \times \quad \mathrm{CH}_{3} t \mathrm{Bu}\right) ; \quad \mathrm{HRMS}(\mathrm{ESI}) \mathrm{m} / \mathrm{z}$ calcd for $\left[\mathrm{C}_{24} \mathrm{H}_{45} \mathrm{~N}_{2} \mathrm{O}_{10} \mathrm{Na}\right]^{+}$: 543.2888, obsd: 543.2891.

$\mathrm{N}$-Azidoacetyl-1,1,1-tris(1,1,1-tris[tert-butyloxycarbonylmethyloxymethyl]methylamidocarbonylmethylamidocarbonylmethyloxymethyl)aminomethane (5). First generation tri-acid 12 (118 mg, $0.31 \mathrm{mmol})$ and primary amine $13(728 \mathrm{mg}, 1.40 \mathrm{mmol})$ were co- 
evaporated with DMF $(2 \times 5 \mathrm{~mL})$. To the mixture DMF $(3.1 \mathrm{~mL})$, HBTU (590 mg, $1.56 \mathrm{mmol}$ ) and $\mathrm{NEt}_{3}(0.65 \mathrm{~mL}, 4.67 \mathrm{mmol})$ were added and the reaction mixture was stirred at r.t. for $14 \mathrm{~h}$. The reaction mixture was diluted with $\mathrm{Et}_{2} \mathrm{O}(50 \mathrm{~mL})$ and washed with $0.1 \mathrm{M} \mathrm{HCl}$ (aq.) $(2 \times 50 \mathrm{~mL})$. The combined water layers were extracted with $\mathrm{Et}_{2} \mathrm{O}(2 \times 50 \mathrm{~mL})$ and the combined organic layers were dried with $\mathrm{MgSO}_{4}$, filtered and concentrated in vacuo. The residue was purified by silica gel column chromatography (PE/ EtOAc, 75/25 $\rightarrow$ 0/100, v/v; followed by EtOAc/MeOH 100/0 $\rightarrow$ $95 / 5, v / v)$ and reverse phase column chromatography $\left(\mathrm{C}_{18}, \mathrm{H}_{2} \mathrm{O} /\right.$ $\mathrm{MeOH}, 50 / 50 \rightarrow 0 / 100, \mathrm{v} / \mathrm{v})$ yielded second generation dendron 5 as a colourless oil ( $475 \mathrm{mg}, 0.25 \mathrm{mmol}, 81 \%) . R_{\mathrm{f}}=0.48$ (EtOAc/ $\mathrm{MeOH}, 95 / 5, \mathrm{v} / \mathrm{v}$ ); IR (film) 3316, 3970, 2934, 2107, 1745, 1670, 1526, 1368, 1231, 1159, 1120, 917, 846, $731 \mathrm{~cm}^{-1}$; ${ }^{1} \mathrm{H}$ NMR $\left(500 \mathrm{MHz}, \mathrm{D}_{2} \mathrm{O}\right) \delta 7.62(\mathrm{~s}, 3 \mathrm{H}, 3 \times \mathrm{NH}-\mathrm{TRIS}), 7.44\left(\mathrm{~s}, 1 \mathrm{H}, 1 \times \mathrm{NH}^{-}\right.$ TRIS), 7.24 (t, $3 \mathrm{H}, J_{\mathrm{NH}, \mathrm{CH}_{2}}=5.0 \mathrm{~Hz}, 3 \times \mathrm{NH}$ gly), $4.06(\mathrm{~s}, 6 \mathrm{H}, 3 \times$ $\left.\mathrm{CH}_{2} \mathrm{C}=\mathrm{O}\right), 4.01\left(\mathrm{~d}, 6 \mathrm{H}, J_{\mathrm{CH}_{2}, \mathrm{NH}}=4.5 \mathrm{~Hz}, 3 \times \mathrm{CH}_{2}-\mathrm{N}\right), 3.98(\mathrm{~s}, 2 \mathrm{H}$, $\mathrm{CH}_{2}-\mathrm{N}_{3}$ ), $3.95\left(\mathrm{~s}, 18 \mathrm{H}, 9 \times \mathrm{CH}_{2} \mathrm{C}=\mathrm{O}\right), 3.93\left(\mathrm{~s}, 6 \mathrm{H}, 3 \times \mathrm{CH}_{2}-\mathrm{O}\right)$, $3.89\left(\mathrm{~s}, 18 \mathrm{H}, 9 \times \mathrm{CH}_{2}-\mathrm{O}\right), 1.45\left(\mathrm{~s}, 54 \mathrm{H}, 18 \times \mathrm{CH}_{3} t-\mathrm{Bu}\right) ;{ }^{13} \mathrm{C} \mathrm{NMR}$ $\left(125 \mathrm{MHz}, \mathrm{CDCl}_{3}\right) \delta 170.3(9 \times \mathrm{C}=\mathrm{O}$ ester $), 169.6(3 \times \mathrm{C}=\mathrm{O}$ amide), $168.5(3 \times \mathrm{C}=\mathrm{O}$ amide $), 168.2(1 \times \mathrm{C}=\mathrm{O}$ amide $), 82.0$ $\left(\mathrm{C}_{\mathrm{q}} t \mathrm{Bu}\right), 70.7\left(3 \times \mathrm{CH}_{2}-\mathrm{O}\right), 70.6\left(3 \times \mathrm{CH}_{2} \mathrm{C}=\mathrm{O}\right), 70.2\left(9 \times \mathrm{CH}_{2}-\right.$ O), $68.9\left(9 \times \mathrm{CH}_{2} \mathrm{C}=\mathrm{O}\right), 60.0\left(3 \times \mathrm{C}_{\mathrm{q}}\right.$ tris $), 59.8\left(1 \times \mathrm{C}_{\mathrm{q}}\right.$ tris $) 52.5$ $\left(\mathrm{CH}_{2}-\mathrm{N}_{3}\right), 42.2\left(3 \times \mathrm{CH}_{2}-\mathrm{NH}\right), 28.3\left(27 \times \mathrm{CH}_{3} t \mathrm{Bu}\right) ; \mathrm{HRMS}(\mathrm{ESI})$ $m / z$ calcd for $\left[\mathrm{C}_{84} \mathrm{H}_{146} \mathrm{~N}_{10} \mathrm{O}_{37}\right]^{2+}$ : 943.4920, obsd: 943.4929 .

$N$-(2-D-Biotinylamido-acetyl)-1,1,1-tris(1,1,1-tris[tert-butyl-oxycarbonylmethyloxymethyl]methylamidocarbonyl-methylamidocarbonylmethyloxymethyl)aminomethane (14). To a solution of second generation dendron $5(139 \mathrm{mg}, 73.7 \mu \mathrm{mol})$ in ethanol ( $1 \mathrm{~mL})$ and THF ( $1 \mathrm{~mL})$, activated RANEY® nickel $(100 \mathrm{mg})$ was added and hydrogen gas was bubbled through the reaction mixture at r.t. for $20 \mathrm{~h}$. The reaction mixture was filtered, washed with sat. aq. $\mathrm{NaCl}(50 \mathrm{~mL})$ containing $1 \mathrm{M} \mathrm{NaOH}(1 \mathrm{~mL})$, extracted with $\mathrm{CH}_{2} \mathrm{Cl}_{2}(2 \times 50 \mathrm{~mL})$ and concentrated in vacuo. The resulting oil was then passed through a silica gel plug $($ EtOAc/MeOH, $100 / 0 \rightarrow 85 / 15, \mathrm{v} / \mathrm{v})$ to yield crude amine as a colourless oil, which was then used without further purification. HRMS(ESI) $m / z$ calcd for $\left[\mathrm{C}_{84} \mathrm{H}_{148} \mathrm{~N}_{8} \mathrm{O}_{37}\right]^{2+}$ : 930.4967, obsd: 930.4960. To the crude second generation dendron amine in DMF (0.73 mL), D-biotin (27.0 mg, $110 \mu \mathrm{mol})$, HBTU (55.9 mg, $147 \mu \mathrm{mol})$ and $\mathrm{NEt}_{3}(25 \mu \mathrm{L})$ were added and the reaction mixture was stirred at r.t. for $18 \mathrm{~h}$. The reaction was diluted with $\mathrm{Et}_{2} \mathrm{O}(50 \mathrm{~mL})$ and washed with sat. aq. $\mathrm{NaCl}(2 \times 50 \mathrm{~mL})$. The combined water layers were extracted with $\mathrm{Et}_{2} \mathrm{O}(2 \times 50 \mathrm{~mL})$ and the combined organic layers were dried with $\mathrm{MgSO}_{4}$, filtered and concentrated in vacuo. Purification by column chromatography $\left(\mathrm{CH}_{2} \mathrm{Cl}_{2} / \mathrm{MeOH}, 100 / 0 \rightarrow 90 / 10, \mathrm{v} / \mathrm{v}\right)$ and reverse phase column chromatography $\left(\mathrm{C}_{18}, \mathrm{H}_{2} \mathrm{O} / \mathrm{MeOH}, 50 / 50\right.$ $\rightarrow$ 0/100, v/v) yielded second-generation dendron 14 as a colourless oil (146 mg, $70.1 \mu \mathrm{mol}, 95 \%) . R_{\mathrm{f}}=0.50\left(\mathrm{CH}_{2} \mathrm{Cl}_{2} / \mathrm{MeOH}\right.$, 90/10, v/v); IR (film) 3309, 3064, 2979, 2933, 1744, 1668, 1527, 1368, 1230, 1158, 1118, 1035, 846, $733 \mathrm{~cm}^{-1}$; ${ }^{1} \mathrm{H}$ NMR $(500 \mathrm{MHz}$, $\left.\mathrm{CDCl}_{3}\right) \delta 7.66\left(\mathrm{~s}, 3 \mathrm{H}, 3 \times \mathrm{NH}\right.$-TRIS), $7.64\left(\mathrm{t}, 1 \mathrm{H}, J_{\mathrm{CH}_{2}, \mathrm{NH}}=5.7 \mathrm{~Hz}\right.$, NH-gly), 7.57 (s, 1H, NH-TRIS), 7.54 (t, 3H, $J_{C_{2}, N H}=5.1 \mathrm{~Hz}, 3 \times$ NH-gly), 6.30 (s, 1H, NH biotin), 5.65 (s, 1H, NH biotin), 4.45 (dd, $1 \mathrm{H}, J_{7,8 a}=5.3 \mathrm{~Hz}, J_{6,7}=7.0 \mathrm{~Hz}, \mathrm{H} 7$-biotin), 4.27 (dd, $1 \mathrm{H}, J_{5,6}$ $=5.1 \mathrm{~Hz}, J_{6,7}=7.0 \mathrm{~Hz}$, H6-biotin), $4.00\left(\mathrm{~s}, 6 \mathrm{H}, 3 \times \mathrm{CH}_{2} \mathrm{O}\right), 3.97$ (t, $\left.6 \mathrm{H}, J_{\mathrm{CH}_{2}, N H}=4.3 \mathrm{~Hz}, 3 \times \mathrm{CH}_{2} \mathrm{~N}\right), 3.92\left(\mathrm{~s}, 18 \mathrm{H}, 9 \times \mathrm{CH}_{2} \mathrm{O}\right)$, 3.88-3.80 (m, 26H, $\left.9 \times \mathrm{CH}_{2} \mathrm{C}=\mathrm{O}, 3 \times \mathrm{CH}_{2} \mathrm{C}=\mathrm{O}, \mathrm{CH}_{2} \mathrm{~N}\right), 3.08$ $\left(\mathrm{dt}, 1 \mathrm{H}, J_{5,6}=4.8 \mathrm{~Hz}, J_{4,5}=7.0 \mathrm{~Hz}\right.$, H5-biotin), 2.85 (dd, $1 \mathrm{H}, J_{7,8 a}$ $=5.3 \mathrm{~Hz}, J_{8 a, s b}=13.0 \mathrm{~Hz}$, H8a-biotin), $2.69\left(\mathrm{~d}, 1 \mathrm{H}, J_{8 a, 8 b}=\right.$ $12.8 \mathrm{~Hz}$, H8b-biotin), 2.28-2.16 (m, $2 \mathrm{H}, \mathrm{CH}_{2}$-1-biotin), 1.71-1.50 (m, 6H, $\mathrm{CH}_{2}-2, \mathrm{CH}_{2}-3, \mathrm{CH}_{2}$-4-biotin), $1.41\left(\mathrm{~s}, 81 \mathrm{H}, 27 \times \mathrm{CH}_{3}\right.$ $t \mathrm{Bu}) ;{ }^{13} \mathrm{C}$ NMR (125 MHz, $\left.\mathrm{CDCl}_{3}\right) \delta 174.4$ (C=O biotin), 170.6 $(\mathrm{C}=\mathrm{O}$ dendron $), 170.1(9 \times \mathrm{C}=\mathrm{O}), 170.0(3 \times \mathrm{C}=\mathrm{O}), 169.0(3 \times$ $\mathrm{C}=\mathrm{O}), 163.9\left(\mathrm{C}=\mathrm{O}\right.$ urea biotin), $81.9\left(9 \times \mathrm{C}_{\mathrm{q}} t \mathrm{Bu}\right), 70.6(3 \times$ $\left.\mathrm{CH}_{2} \mathrm{C}=\mathrm{O}\right), 70.4\left(3 \times \mathrm{CH}_{2}-\mathrm{O}\right), 70.0\left(9 \times \mathrm{CH}_{2}-\mathrm{O}\right), 68.8(9 \times$ $\mathrm{CH}_{2} \mathrm{C}=\mathrm{O}$ ), 61.8 (C6-biotin), 60.1 (C7-biotin), $59.9\left(3 \times \mathrm{C}_{\mathrm{q}}\right.$ tris), $59.5\left(1 \times \mathrm{C}_{\mathrm{q}}\right.$ tris), 55.5 (C5-biotin), $43.7\left(1 \times \mathrm{CH}_{2}-\mathrm{N}\right), 42.2(3 \times$ $\mathrm{CH}_{2}-\mathrm{N}$ ), 40.3 (C8-biotin), 35.2 (C1-biotin), 28.2 (C2-biotin), 28.0 (27 $\times \mathrm{CH}_{3}$ ), 27.9 (C4-biotin), 25.3 (C3-biotin); HRMS(ESI) $\mathrm{m} / \mathrm{z}$ calcd for $\left[\mathrm{C}_{94} \mathrm{H}_{162} \mathrm{~N}_{10} \mathrm{O}_{39} \mathrm{~S}\right]^{2+}: 1043.5355$, obsd: 1043.5351 .

$N$-(2-D-Biotinylamidoacetyl)-1,1,1-tris(1,1,1-tris[carboxymethyloxymethyl]methylamidocarbonylmethylamidocarbonyl-methyloxymethyl)aminomethane (15). To a solution of second-generation dendron $14(12.0 \mathrm{mg}, 5.8 \mu \mathrm{mol})$ in $\mathrm{CH}_{2} \mathrm{Cl}_{2}(1 \mathrm{~mL})$, freshly distilled trifluoroacetic acid $(1 \mathrm{~mL})$ was added and the reaction mixture was stirred at r.t. for $3 \mathrm{~h}$. The crude reaction mixture was concentrated in vacuo and coevaporated with water $(10 \times 1 \mathrm{~mL})$. Purification by reverse phase column chromatography $\left(\mathrm{C}_{18}, \mathrm{H}_{2} \mathrm{O}\right.$ / $\mathrm{MeOH}, 100 / 0 \rightarrow 70 / 30, \mathrm{v} / \mathrm{v}$ ) yielded nona-acid 15 (8.8 mg, $5.6 \mathrm{mmol}, 97 \%$ ). $R_{\mathrm{f}}=0.1$ (EtOAc/MeOH, 80/20, v/v); IR (film) 3360, 3005, 2990, 2978, 2948, 1721, 1656, 1552, 1472, 1431, 1343, 1245, 1200, 1123, 1032, 1018, $979 \mathrm{~cm}^{-1}$; ${ }^{1} \mathrm{H}$ NMR (500 MHz, $\left.\mathrm{D}_{2} \mathrm{O}\right) \delta 4.57$ (dd, $1 \mathrm{H}, J_{7,8 a}=5.1 \mathrm{~Hz}, J_{6,7}=7.5 \mathrm{~Hz}, \mathrm{H} 7$-biotin), 4.39 (dd, $1 \mathrm{H}, J_{5,6}=$ $4.6, J_{6,7}=7.5 \mathrm{~Hz}$, H6-biotin), 4.18 (s, $\left.18 \mathrm{H}, 9 \times \mathrm{CH}_{2} \mathrm{CO}\right), 4.12(\mathrm{~s}, 6 \mathrm{H}$, $\left.3 \times \mathrm{CH}_{2} \mathrm{CO}\right), 3.95\left(\mathrm{~s}, 6 \mathrm{H}, 3 \times \mathrm{CH}_{2} \mathrm{NH}\right), 3.88\left(\mathrm{~s}, 18 \mathrm{H}, 9 \times \mathrm{CH}_{2} \mathrm{O}\right)$, $3.86\left(\mathrm{~s}, 6 \mathrm{H}, 3 \times \mathrm{CH}_{2} \mathrm{O}\right), 3.28\left(\mathrm{dt}, 1 \mathrm{H}, J_{5,6}=5.3 \mathrm{~Hz}, J_{4,5}=8.0 \mathrm{~Hz}, \mathrm{H} 5-\right.$ biotin), 2.96 (dd, $1 \mathrm{H}, J_{7,8 a}=5.0 \mathrm{~Hz}, J_{8 a, 8 b}=13.0 \mathrm{~Hz}$, H8a-biotin), $2.74\left(\mathrm{~d}, 1 \mathrm{H}, J_{8 a, 8 b}=13.0 \mathrm{~Hz}\right.$, H8b-biotin), $2.30\left(\mathrm{t}, 2 \mathrm{H}, J_{1,2}=\right.$ 7.2 Hz, $\mathrm{CH}_{2}$-1-biotin), 1.74-1.50 (m, 4H, $\mathrm{CH}_{2}$-4-biotin, $\mathrm{CH}_{2}$-2biotin), 1.39 (p, 2H, $J_{2,3}=J_{3,4}=7.4 \mathrm{~Hz}, \mathrm{CH}_{2}$-3-biotin); ${ }^{13} \mathrm{C} \mathrm{NMR}(125$ $\left.\mathrm{MHz}, \mathrm{CDCl}_{3}\right) \delta 77.1(\mathrm{C}=\mathrm{O}$ biotin), $174.2(9 \times \mathrm{C}=\mathrm{O}), 172.8(3 \times$ $\mathrm{C}=\mathrm{O}), 171.3(1 \times \mathrm{C}=\mathrm{O}), 170.7(3 \times \mathrm{C}=\mathrm{O}), 165.2(\mathrm{C}=\mathrm{O}$ urea biotin), $70.0\left(3 \times \mathrm{CH}_{2} \mathrm{C}=\mathrm{O}\right), 69.8\left(3 \times \mathrm{CH}_{2}-\mathrm{O}\right), 69.7\left(9 \times \mathrm{CH}_{2}-\mathrm{O}\right)$, $68.0\left(9 \times \mathrm{CH}_{2} \mathrm{C}=\mathrm{O}\right), 62.0$ (C6-biotin), 60.2 (C7-biotin), $59.8\left(3 \times \mathrm{C}_{\mathrm{q}}\right.$ tris), $59.6\left(1 \times \mathrm{C}_{\mathrm{q}}\right.$ tris), 55.2 (C5-biotin), $43.0\left(1 \times \mathrm{CH}_{2}-\mathrm{N}\right), 42.4(3 \times$ $\mathrm{CH}_{2}-\mathrm{N}$ ), 39.6 (C8-biotin), 35.1 (C1-biotin), 27.9 (C2-biotin), 27.6 (C4-biotin), 25.0 (C3-biotin); HRMS(ESI) $\mathrm{m} / \mathrm{z}$ calcd for $\left[\mathrm{C}_{58} \mathrm{H}_{90} \mathrm{~N}_{10} \mathrm{O}_{39} \mathrm{~S}\right]^{2+}$ : 791.2538, obsd: 791.2536.

$N$-(2-D-Biotinylamido-acetyl)-1,1,1-tris(1,1,1-tris[3-( $N$-(2-acetamido-2-deoxy- $\beta$-D-glucopyranosyl)- $O$-methyl-hydroxylamine) propylamidocarbonylmethyloxymethyl]methyl-amidocarbonylmethylamidocarbonylmethyloxy-methyl)aminomethane (17). Second-generation dendron nona-acid $15(1.5 \mathrm{mg}, 0.95 \mu \mathrm{mol})$ and GlcNAc-amine $16(5.3 \mathrm{mg}, 17.1 \mu \mathrm{mol})$ were co-evaporated with freshly distilled DMF $(2 \times 2 \mathrm{~mL})$. To the mixture DMF $(0.2 \mathrm{~mL})$ was added and the reaction mixture was half concentrated under reduced pressure to remove traces of $\mathrm{Et}_{2} \mathrm{NH}$. To the reaction mixture, HBTU $(13.7 \mathrm{mg}, 36 \mu \mathrm{mol})$ and distilled $\mathrm{NEt}_{3}(25 \mu \mathrm{L})$ were added and the reaction mixture was stirred at r.t. for $14 \mathrm{~h}$. The reaction mixture was diluted with water $(2 \mathrm{~mL})$ and purified using a dialysis in a $\mathrm{Na}_{2} \mathrm{HPO}_{4}$ solution $\left(1 \mathrm{~g} \mathrm{~L}^{-1}\right)$, to remove the conjugation byproducts. The water 
was replaced twice a day for 4 days. The dendron was then purified using reverse phase column chromatography $\left(\mathrm{C}_{8}, \mathrm{H}_{2} \mathrm{O} /\right.$ $\mathrm{MeOH}, 100 / 0 \rightarrow 70 / 30, \mathrm{v} / \mathrm{v})$ to give glycodendron 17 as a colourless oil (2.8 mg, $0.68 \mu \mathrm{mol}, 72 \%) .{ }^{1} \mathrm{H}$ NMR (600 MHz, $\mathrm{D}_{2} \mathrm{O}$ ) $\delta 4.58$ (dd, $1 \mathrm{H}, J_{7,8 a}=5.1 \mathrm{~Hz}, J_{6,7}=7.7 \mathrm{~Hz}, \mathrm{H} 7$-biotin), 4.40 (dd, $1 \mathrm{H}, J_{5,6}=4.7 \mathrm{~Hz}, J_{6,7}=7.7 \mathrm{~Hz}$, H6-biotin), 4.32 (d, 9H, $J_{1,2}=$ $9.7 \mathrm{~Hz}, 9 \times \mathrm{H}-1 \mathrm{GlcNAc}), 4.12$ (s, $6 \mathrm{H}, 3 \times \mathrm{CH}_{2} \mathrm{C}=\mathrm{O}$ dendron), 4.07 (s, $18 \mathrm{H}, 9 \times \mathrm{CH}_{2} \mathrm{C}=\mathrm{O}$ dendron), $3.96\left(\mathrm{~s}, 6 \mathrm{H}, 3 \times \mathrm{CH}_{2}-\mathrm{N}\right.$ dendron), 3.92-3.83 (m, 37H, $1 \times \mathrm{CH}_{2} \mathrm{~N}$ dendron, $9 \times \mathrm{H}-2$ GlcNAc, $9 \times$ H-6a GlcNAc, $9 \times \mathrm{CH}_{2}$-dendron), 3.72 (dd, 9H, $J_{5,6 a}=5.5 \mathrm{~Hz}, J_{6 a, 6 b}=12.4 \mathrm{~Hz}, 9 \times \mathrm{H}-6 \mathrm{~b}$ GlcNAc), 3.51 (dd, $9 \mathrm{H}$, $\left.J_{2,3}=8.8 \mathrm{~Hz}, J_{3,4}=9.8 \mathrm{~Hz}, 9 \times \mathrm{H}-3 \mathrm{GlcNAc}\right), 3.48(\mathrm{~s}, 27 \mathrm{H}, 9 \times$ $\left.\mathrm{NOCH}_{3}\right), 3.43-3.28\left(\mathrm{~m}, 28 \mathrm{H}, 9 \times \mathrm{CH}_{2} \mathrm{a}-3\right.$ linker, $9 \times \mathrm{H}-4$ GlcNAc, $9 \times \mathrm{H}-5$ GlcNAc, H5-biotin), $3.24\left(\mathrm{dt}, 9 \mathrm{H}, J_{2,3}=\right.$ $7.2 \mathrm{~Hz}, J_{3 a, 3 b}=13.4 \mathrm{~Hz}, 9 \times \mathrm{CH}_{2} \mathrm{~b}-3$ linker$), 3.01-2.87(\mathrm{~m}, 19 \mathrm{H}$, $9 \times \mathrm{CH}_{2}-1$ linker, H8a-biotin), $2.75\left(\mathrm{~d}, 1 \mathrm{H}, J_{8 a, 8 b}=12.9 \mathrm{~Hz}\right.$, H8b-biotin), 2.30 (t, 2H, $J_{1,2}=7.3 \mathrm{~Hz}, \mathrm{CH}_{2}$-1-biotin), 2.03 (s, $27 \mathrm{H}, 9 \times N$-Ac) $, 1.88-1.78(\mathrm{~m}, 1 \mathrm{H}, \mathrm{H} 4 \mathrm{a}-$ biotin $), 1.77-1.69(\mathrm{~m}$, $18 \mathrm{H}, 9 \times \mathrm{CH}_{2}$-2 linker), 1.69-1.58 (m, 1H, H4a-biotin) 1.58-1.50 (m, 2H, $\mathrm{CH}_{2}$-2-biotin), 1.44-1.36 (m, 2H, $\mathrm{CH}_{2}$-3-biotin); HRMS(ESI) $m / z$ calcd for $\left[\mathrm{C}_{166} \mathrm{H}_{298} \mathrm{~N}_{37} \mathrm{O}_{84} \mathrm{~S}\right]^{3+}: 1395.6641$, obsd: 1395.6648.

$N$-Glycyl-1,1,1-tris(1,1,1-tris[carboxy-methyloxymethyl]methylamidocarbonylmethylamidocarbonylmethyloxymethyl)aminomethane trifluoroacetic acid (21). To a solution dendron 5 (60.5 mg, $31.8 \mu \mathrm{mol})$ in $\mathrm{MeOH} / \mathrm{H}_{2} \mathrm{O} / \mathrm{CH}_{2} \mathrm{Cl}_{2}(3 \mathrm{~mL}, 3 / 1 / 1, \mathrm{v} / \mathrm{v} / \mathrm{v})$, triphenylphosphine $(25.0 \mathrm{mg}, 95.4 \mu \mathrm{mol})$ was added and the reaction mixture was stirred at r.t. for $18 \mathrm{~h}$. The crude reaction mixture was concentrated in vacuo and co-evaporated with $\mathrm{CH}_{2} \mathrm{Cl}_{2}(2 \times 10 \mathrm{~mL})$. The residue was dissolved in $\mathrm{CH}_{2} \mathrm{Cl}_{2}(3$ $\mathrm{mL})$, TFA $(3 \mathrm{~mL})$ was added and the reaction mixture was stirred at r.t. for $3 \mathrm{~h}$. The solvent was evaporated by an argon stream, $\mathrm{H}_{2} \mathrm{O}(10 \mathrm{~mL})$ was added, and the phosphine salts were removed via filtration, and the resulting residue was concentrated in vacuo to give crude amino acid 21. (45.9 $\mathrm{mg}, 31.6$ $\mu \mathrm{mol}, 99 \%) . R_{\mathrm{f}}=0.05\left(t \mathrm{BuOH} / \mathrm{AcOH} / \mathrm{H}_{2} \mathrm{O}, 4 / 1 / 1, \mathrm{v} / \mathrm{v} / \mathrm{v}\right) ; \mathrm{IR}$ (film) 3344, 3003, 2981, 2950, 2937, 2930, 1718, 1651, 1543, 1473, 1458, 1434, 1241, 1199, 1120, 1032, $952 \mathrm{~cm}^{-1} ;{ }^{1} \mathrm{H}$ NMR $\left(500 \mathrm{MHz}, \mathrm{D}_{2} \mathrm{O}\right) \delta 4.06\left(\mathrm{~s}, 18 \mathrm{H}, 9 \times \mathrm{CH}_{2} \mathrm{C}=\mathrm{O}\right), 4.00(\mathrm{~s}, 6 \mathrm{H}, 3 \times$ $\left.\mathrm{CH}_{2} \mathrm{C}=\mathrm{O}\right), 3.83\left(\mathrm{~s}, 6 \mathrm{H}, 3 \times \mathrm{CH}_{2} \mathrm{~N}\right), 3.77\left(\mathrm{~s}, 6 \mathrm{H}, 3 \times \mathrm{CH}_{2} \mathrm{O}\right), 3.75$ $\left(\mathrm{s}, 18 \mathrm{H}, 9 \times \mathrm{CH}_{2} \mathrm{O}\right), 3.71\left(\mathrm{~s}, 2 \mathrm{H}, 1 \times \mathrm{CH}_{2} \mathrm{NH}_{2}\right) ;{ }^{13} \mathrm{C}$ NMR $(125$ $\left.\mathrm{MHz}, \mathrm{D}_{2} \mathrm{O}\right) \delta 174.1\left(9 \times \mathrm{C}=\mathrm{O} \mathrm{CO}_{2} \mathrm{H}\right), 172.6(3 \times \mathrm{C}=\mathrm{ONH})$, $170.6(3 \times \mathrm{C}=\mathrm{O}), 166.7(1 \times \mathrm{C}=\mathrm{O}), 162.8,162.5,162.2,161.9$ (C=O TFA), 119.4, 117.1, 114.8, 112.5 ( $\mathrm{CF}_{3}$ TFA), 69.83, 69.77 (3 $\left.\times \mathrm{CH}_{2} \mathrm{O}, 3 \times \mathrm{CH}_{2} \mathrm{C}=\mathrm{O}\right), 69.6\left(9 \times \mathrm{CH}_{2} \mathrm{O}\right), 67.9\left(9 \times \mathrm{CH}_{2} \mathrm{C}=\mathrm{O}\right)$, $59.9\left(1 \times \mathrm{C}_{\mathrm{q}}\right.$ tris $), 59.7\left(3 \times \mathrm{C}_{\mathrm{q}}\right.$ tris $), 42.3\left(3 \times \mathrm{CH}_{2} \mathrm{NH}\right), 40.6(1$ $\times \mathrm{CH}_{2} \mathrm{NH}_{2}$ ); HRMS(ESI) $\mathrm{m} / \mathrm{z}$ calcd for $\left[\mathrm{C}_{48} \mathrm{H}_{76} \mathrm{~N}_{8} \mathrm{O}_{37}\right]^{2+}$ : 678.2150, obsd: 678.2136 .

$N-\left[N-\left(\left[\left(3^{\prime}, 6^{\prime}\right.\right.\right.\right.$-Dihydroxy-3-oxospiro[isobenzofuran-1 $(3 H), 9^{\prime}-(9 H)-$ xanthen]-5-yl)amino]-thioxomethyl)glycyl]-1,1,1-tris(1,1,1-tris [carboxymethyloxymethyl]methylamido-carbonylmethylamidocarbonylmethyloxymethyl)aminomethane (22). To a solution of dendron 21 (25.1 mg, $17.3 \mu \mathrm{mol})$ in DMF (3 mL), fluorescein isothiocyanate isomer $\mathrm{I}(7.4 \mathrm{mg}, 19.0 \mu \mathrm{mol})$ and $\mathrm{Et}_{3} \mathrm{~N}(1 \mathrm{~mL})$ were added and the reaction mixture was stirred at r.t. for $18 \mathrm{~h}$. The crude reaction mixture was concentrated in vacuo. The residue was purified with size exclusion chromatography (LH-
20, $\mathrm{CH}_{2} \mathrm{Cl}_{2} / \mathrm{MeOH}, 50 / 50, \mathrm{v} / \mathrm{v}$ ) and concentrated in vacuo to give the trimethylamine salt of dendron 22. The dendron was co-evaporated with $\mathrm{H}_{2} \mathrm{O}$ and purified using ion exchange chromatography (Dowex $\mathrm{H}^{+}$, elute with $\mathrm{H}_{2} \mathrm{O}$ ) to give dendron 22 (22.3 mg, $12.8 \mathrm{mmol}, 74 \%)$ as a yellow oil. $R_{\mathrm{f}}=0.05(t \mathrm{BuOH} /$ $\mathrm{AcOH} / \mathrm{H}_{2} \mathrm{O}, 4 / 1 / 1, \mathrm{v} / \mathrm{v} / \mathrm{v}$ ); IR (film) 3463, 3366, 3074, 3015, 2970, 2946, 1738, 1656, 1548, 1436, 1366, 1229, 1216, 1206, 1119, 1051, 1032, $897 \mathrm{~cm}^{-1} ;{ }^{1} \mathrm{H}$ NMR (500 MHz, CD 3 OD) $\delta 8.22(\mathrm{~s}, 1 \mathrm{H}$, $\mathrm{H}-3)$, 8.13-7.98 (m, NH), $7.94(\mathrm{~s}, 3 \times \mathrm{NH}), 7.88(\mathrm{~s}, 1 \times \mathrm{NH}), 7.84$ $\left(\mathrm{d}, 1 \mathrm{H}, J_{5,6}=8.8 \mathrm{~Hz}, \mathrm{H}-5\right), 7.17\left(\mathrm{~d}, 1 \mathrm{H}, J_{5,6}=8.8 \mathrm{~Hz}, \mathrm{H}-6\right), 6.78-$ $6.63(\mathrm{~m}, 4 \mathrm{H}, 2 \times \mathrm{H}-13,2 \times \mathrm{H}-10), 6.58\left(\mathrm{~d}, 2 \mathrm{H}, J_{9,10}=8.2 \mathrm{~Hz}, 2 \times\right.$ $\mathrm{H}-11), 4.35$ (s, 2H, $\left.1 \times \mathrm{CH}_{2} \mathrm{NH}\right), 4.20-4.02\left(\mathrm{bs}, 24 \mathrm{H}, 3 \times \mathrm{CH}_{2} \mathrm{C}=\right.$ $\left.\mathrm{O}, 9 \times \mathrm{CH}_{2} \mathrm{C}=\mathrm{O}\right), 4.02-3.92\left(\mathrm{~m}, 12 \mathrm{H}, 3 \times \mathrm{CH}_{2} \mathrm{O}, 3 \times \mathrm{CH}_{2} \mathrm{NH}\right)$, 3.92-3.86 (m, 18H, $\left.9 \times \mathrm{CH}_{2} \mathrm{O}\right) ;{ }^{13} \mathrm{C} \mathrm{NMR}\left(125 \mathrm{MHz}, \mathrm{CD}_{3} \mathrm{OD}\right)$ $\delta 183.5(\mathrm{C}=\mathrm{S}), 174.5(9 \times \mathrm{C}=\mathrm{O}), 173.0(3 \times \mathrm{C}=\mathrm{O}), 172.0(1 \times$ $\mathrm{C}=\mathrm{O}$ glyc $), 171.4(3 \times \mathrm{C}=\mathrm{O}$ glyc $), 171.2(\mathrm{C}=\mathrm{O} \mathrm{C}-1), 161.5,154.2$ (C-12, C14), 149.7 (C-7), 142.2 (C-2/4/8), 132.1 (C-5), 130.4 (C13), 130.3 (C-2/4/8), 128.9 (C-2/4/8), 125.8 (C-6), 120.3 (C-3), 113.8 (C-11), 111.5 (C-9), 103.6 (C-10), $71.4\left(3 \times \mathrm{CH}_{2}-\mathrm{O}\right), 71.0$ $\left(9 \times \mathrm{CH}_{2} \mathrm{O}\right), 69.3\left(3 \times \mathrm{CH}_{2} \mathrm{C}=\mathrm{O}\right), 69.2\left(9 \times \mathrm{CH}_{2} \mathrm{C}=\mathrm{O}\right), 61.3(3 \times$ $\mathrm{C}_{\mathrm{q}}$ tris $), 61.2\left(1 \times \mathrm{C}_{\mathrm{q}}\right.$ tris $), 48.9\left(1 \times \mathrm{CH}_{2} \mathrm{NH}\right), 43.5\left(3 \times \mathrm{CH}_{2} \mathrm{NH}\right)$; HRMS(ESI) $\mathrm{m} / \mathrm{z}$ calcd for $\left[\mathrm{C}_{69} \mathrm{H}_{87} \mathrm{~N}_{9} \mathrm{O}_{42} \mathrm{~S}\right]^{2+}: 872.7329$, obsd: 872.7335.

$\mathrm{N}$-(2-Acetamido-2-deoxy-3-O-( $\alpha$-L-fuco-pyranosyl)-4- $O$ - $(\beta$-Dgalactopyranosyl)- $\beta$-D-glucopyranosyl)- $N$-(3-aminopropyl)-Omethylhydroxylamine (24). To a solution of Lewis ${ }^{\mathrm{X}} 23$ $(5.6 \mathrm{mg}, 10.6 \mu \mathrm{mol})$, in a $\mathrm{AcOH} / \mathrm{NH}_{4} \mathrm{OAc}$ buffer $(0.5 \mathrm{~mL}, 2 \mathrm{M}$, freshly prepared, $\mathrm{pH} 4.5$ ), 3-(methoxyamino)propanyl-amine hydrochloride $4(15.9 \mathrm{mg}, 113.2 \mu \mathrm{mol})$ was added and the reaction mixture was stirred at $40{ }^{\circ} \mathrm{C}$ for $35 \mathrm{~h}$. The crude mixture was directly loaded onto a size exclusion column (Bio-Gel P-2, $1200 \times 18 \mathrm{~mm}$ ) and eluted with $0.1 \mathrm{M}$ aq. $\mathrm{NH}_{4} \mathrm{HCO}_{2}$. Lyophilisation of the product fractions afforded neoglycoside $24(5.7 \mathrm{mg}, 88 \%) . R_{\mathrm{f}}=0.10\left(\mathrm{CH}_{2} \mathrm{Cl}_{2} / \mathrm{EtOH} /\right.$ $\mathrm{MeOH} / \mathrm{NH}_{3}$ (aq. 35\%), 5/2/2/1, v/v/v/v); $\alpha_{\mathrm{D}}^{19.5}=-9.3(c=0.2$, $\mathrm{MeOH}$ ); IR (film) 3341, 2925, 2852, 17 117, 1647, 1586, 1466, 1451, 1415, 1380, 1350, 1302, 1233, 1193, 1085, 1026, 968, $917 \mathrm{~cm}^{-1} ;{ }^{1} \mathrm{H}$ NMR $\left(500 \mathrm{MHz}, \mathrm{D}_{2} \mathrm{O}\right) \delta 5.12\left(\mathrm{~d}, 1 \mathrm{H}, J_{1^{\prime \prime \prime}, 2^{\prime \prime \prime}}=\right.$ $\left.3.9 \mathrm{~Hz}, \mathrm{H}-1^{\prime \prime \prime}\right), 4.84$ (q, $\left.1 \mathrm{H}, J_{5^{\prime \prime \prime}, 6^{\prime \prime \prime}}=6.7 \mathrm{~Hz}, \mathrm{H}-5^{\prime \prime \prime}\right)$, 4.49-4.42 $\left(\mathrm{m}, 1 \mathrm{H}, \mathrm{H}-1^{\prime}, \mathrm{H}-1^{\prime \prime}\right), 4.05\left(\mathrm{~m}, 2 \mathrm{H}, \mathrm{H}-2^{\prime}, \mathrm{H}-6 \mathrm{a}^{\prime}\right), 3.93-3.81$ (m, $\left.5 \mathrm{H}, \mathrm{H}-3^{\prime \prime \prime}, \mathrm{H}-4^{\prime \prime}, \mathrm{H}-4^{\prime}, \mathrm{H}-3^{\prime}, \mathrm{H}-6 \mathrm{~b}^{\prime}\right), 3.80\left(\mathrm{~d}, 1 \mathrm{H}, J_{3^{\prime \prime \prime}, 4^{\prime \prime \prime}}=J_{4^{\prime \prime \prime}, 5^{\prime \prime \prime}}=\right.$ $2.9 \mathrm{~Hz}, \mathrm{H}-4^{\prime \prime \prime}$ ), 3.76 (m, 3H, H-6a" , H-6b" , H-2 ${ }^{\prime \prime \prime}$ ), 3.64 (dd, 1H, $\left.J_{3^{\prime \prime}, 4^{\prime \prime}}=3.2 \mathrm{~Hz}, J_{2^{\prime \prime}, 3^{\prime \prime}}=9.9 \mathrm{~Hz}, \mathrm{H}-3^{\prime \prime}\right), 3.60-3.55\left(\mathrm{~m}, 1 \mathrm{H}, \mathrm{H}-5^{\prime \prime}\right)$, 3.54-3.46 (m, $\left.1 \mathrm{H}, \mathrm{H}-5^{\prime \prime}\right), 3.54-3.46$ (m, 5H, $\mathrm{OCH}_{3}, \mathrm{H}-5^{\prime}, \mathrm{H}-2^{\prime \prime}$ ), 3.11-2.92 (m, 4H, $\left.\mathrm{CH}_{2}-1, \mathrm{CH}_{2}-3\right), 2.02$ (s, 3H, $\left.\mathrm{CH}_{3} \mathrm{Ac}\right), 1.95$ $\left(\mathrm{m}, 2 \mathrm{H}, \mathrm{CH}_{2}-2\right), 1.17$ (d, 3H, $\left.J_{5^{\prime \prime \prime}, 6^{\prime \prime \prime}}=6.7 \mathrm{~Hz}, \mathrm{H}-6^{\prime \prime \prime}\right) ;{ }^{13} \mathrm{C} \mathrm{NMR}$ (125 MHz, D $2 \mathrm{O}) 170.5(\mathrm{C}=\mathrm{O}), 101.8\left(\mathrm{C}-1^{\prime \prime}\right), 98.7\left(\mathrm{C}-1^{\prime \prime \prime}\right), 90.5$ $\left(\mathrm{C}-1^{\prime}\right), 76.9\left(\mathrm{C}-5^{\prime}\right), 76.1\left(\mathrm{C}-3^{\prime}\right), 74.8\left(\mathrm{C}-5^{\prime \prime}\right), 73.2\left(\mathrm{C}-4^{\prime}\right), 72.4$ $\left(\mathrm{C}-3^{\prime \prime}\right), 71.8\left(\mathrm{C}-4^{\prime \prime \prime}\right), 70.9\left(\mathrm{C}-2^{\prime \prime}\right), 69.1\left(\mathrm{C}-3^{\prime \prime \prime}\right), 68.3\left(\mathrm{C}-4^{\prime \prime}\right), 67.6$ $\left(\mathrm{C}-2^{\prime \prime \prime}\right), 66.7\left(\mathrm{C}-5^{\prime \prime \prime}\right), 61.4\left(\mathrm{C}-6^{\prime \prime}\right), 60.9\left(\mathrm{OCH}_{3}\right), 59.7\left(\mathrm{C}-6^{\prime}\right), 52.5$ $\left(\mathrm{C}-2^{\prime}\right), 47.2$ (C-1), 37.5 (C-3), 24.5 (C-2), $22.1\left(\mathrm{CH}_{3} \mathrm{Ac}\right), 15.2$ $\left(\mathrm{C}-6^{\prime \prime \prime}\right)$; HRMS(ESI) $m / z$ calcd for $\left[\mathrm{C}_{24} \mathrm{H}_{46} \mathrm{~N}_{3} \mathrm{O}_{15}\right]^{+}:$616.2923, obsd: 616.2938 .

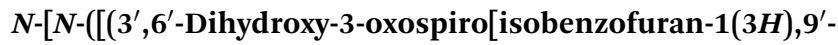
(9H)xanthen]-5-yl)amino]-thioxomethyl)glycyl]-1,1,1-tris(1,1,1tris[3-( $N$-(2-acetamido-2-deoxy-3- $O$ - $(\alpha-\mathrm{L}-$ fuco-pyranosyl)-4- $O$ - $(\beta$ D-galactopyranosyl)- $\beta$-D-gluco-pyranosyl)- $N$-(3-aminopropyl)- $O$-)- $O$ - 
methyl-hydroxylamine)propylamidocarbonylmethyloxymethyl] methylamidocarbonyl-methylamidocarbonylmethyloxy-methyl) aminomethane (25). To the oxyamine-functionalised Lewis trisaccharide 24 (6 mg, $9.8 \mu \mathrm{mol}$ ), a solution of FITC labelled second generation dendron $22(0.94 \mathrm{mg}, 0.54 \mu \mathrm{mol})$ in freshly distilled and half-concentrated DMF $(250 \mu \mathrm{L})$ was added, followed by the addition of HBTU (5.6 mg, $15 \mu \mathrm{mol})$ and $\mathrm{Et}_{3} \mathrm{~N}(10 \mu \mathrm{L}, 72$ $\mu \mathrm{mol})$. The reaction mixture was stirred at r.t. for $18 \mathrm{~h}$. The crude mixture was then diluted with $\mathrm{H}_{2} \mathrm{O}(1 \mathrm{~mL})$ and purified by size exclusion chromatography (Sephadex CM C-25, $0.1 \mathrm{M}$ aq. $\mathrm{NH}_{4} \mathrm{HCO}_{2}$ ). Lyophilisation of the product afforded fluorescent glycodendron 25 (1.9 mg, $0.28 \mu \mathrm{mol}, 51 \%$ ) as a yellow foam. UV-VIS: $\left(\mathrm{H}_{2} \mathrm{O}\right), \lambda_{\mathrm{Abs}, \max }=495 \mathrm{~nm} ;{ }^{1} \mathrm{H} \mathrm{NMR}\left(600 \mathrm{MHz}, \mathrm{D}_{2} \mathrm{O}\right) \delta 8.05(\mathrm{bs}, 1 \mathrm{H})$, 7.88-7.85 (m, 1H), 7.73-7.70 (m, 1H), 7.66-7.64 (m, 1H), 7.38-7.22 $(\mathrm{m}, 4 \mathrm{H}), 6.85-6.58(\mathrm{~m}, 5 \mathrm{H}), 5.12(\mathrm{~d}, 9 \mathrm{H}, J=3.9 \mathrm{~Hz}), 4.84(\mathrm{q}, 9 \mathrm{H}, J=$ $6.7 \mathrm{~Hz}), 4.49-4.42(\mathrm{~m}, 18 \mathrm{H}), 4.41-4.35(\mathrm{~m}, 18 \mathrm{H}), 4.20-3.55(\mathrm{~m}$, $171 \mathrm{H}), 3.54-3.46$ (m, 45H), 3.40-3.16 (m, 27H), 3.03-2.88 (m, 18H), 2.08-1.99 (m, 27H), 1.82-1.65 (m, 18H), 1.17 (d, 27H); HRMS(ESI) $m / z$ calcd for $\left[\mathrm{C}_{285} \mathrm{H}_{476} \mathrm{~N}_{36} \mathrm{O}_{168} \mathrm{~S}\right]^{4+}: 1781.7393$, obsd: 1781.7380 .

\section{THP-1 derived macrophage differentiation}

The THP-1 acute monocytic lymphoma cell line was cultured in RPMI 1640 medium supplemented with 10\% Fetal Calf Serum (FCS), 1\% Glutamax and 1\% Penstrep, and seeded $2.5 \times 10^{5}$ cells per mL. Differentiation of the THP-1 cells was induced via the treatment with PMA (50 ng $\mathrm{mL}^{-1}, 48 \mathrm{~h}$.) followed by addition of IL-4 (20 ng mL ${ }^{-1}, 24 \mathrm{~h}$ ) to obtian 'M2-like' M $\phi$ s according to the procedures of Puig-Kröger et al. ${ }^{29}$ For subsequent analysis, the differentiated cells were detached from the tissue culture plates by incubating the cells in PBS on ice.

\section{Flow cytometry}

The macrophages were stained by incubating for 1 hour at $4{ }^{\circ} \mathrm{C}$ with either FITC-labelled glycodendron 25, negative control (non-glycosylated dendron 22) or anti-DC-SIGN antibody, washed twice with PBS, and DC-SIGN expression measured by flow cytometry. The fluorescent Lewis ${ }^{\mathrm{x}}$ glycodendron and the negative control were used in various concentrations $\left(10^{-1}, 10^{1}\right.$, $10^{2}, 10^{3}, 10^{4}$ and $10^{5} \mathrm{nM}$, diluted in $10 \% \mathrm{FCS}$ ), where the human anti-DC-SIGN antibody (phycoerythrin-labelled) positive control was diluted by a factor $2(1 / 50 \rightarrow 1 / 1600, v / v)$.

\section{Conflicts of interest}

There are no conflicts to declare.

\section{Acknowledgements}

The authors would like to thank the Wellington Medical Research Foundation for financial support and the Health Research Council of New Zealand (Hercus Fellowship, BLS).

\section{Notes and references}

1 S. Weinbaum, J. M. Tarbell and E. R. Damiano, Annu. Rev. Biomed. Eng., 2007, 9, 121-167.
2 R. D. Cummings, Mol. BioSyst., 2009, 5, 1087-1104.

3 (a) M. Mammen, S.-K. Choi and G. M. Whitesides, Angew. Chem., Int. Ed., 1998, 37, 2754-2794; (b) J. J. Lundquist, S. D. Debenham and E. J. Toone, J. Org. Chem., 2000, 65, 8245-8250.

4 C. Müller, G. Despras and T. K. Lindhorst, Chem. Soc. Rev., 2016, 45, 3275-3302.

5 S. Munneke, J. R. Prevost, G. F. Painter, B. L. Stocker and M. S. M. Timmer, Org. Lett., 2015, 17, 624-627.

6 S. Munneke, E. M. Dangerfield, B. L. Stocker and M. S. M. Timmer, Glycoconjugate J., 2017, 34, 633-642.

7 P. Stanley, H. Schachter and N. Taniguchi, N-Glycans, in Essentials of Glycobiology, ed. A. Varki, R. D. Cummings and J. D. Esko, et al., Cold Spring Harbor Laboratory Press, Cold Spring Harbor (NY), 2nd edn, 2009, ch. 8.

8 T. B. Geijtenbeek, R. Torensma, S. J. van Vliet, G. C. van Duijnhoven, G. J. Adema, Y. van Kooyk and C. G. Figdor, Cell, 2000, 100, 575-585.

9 E. J. Soilleux, L. S. Morris, G. Leslie, J. Chehimi, Q. Luo, E. Levroney, J. Trowsdale, L. J. Montaner, R. W. Doms, D. Weissman, N. Coleman and B. Lee, J. Leukocyte Biol., 2002, 71, 445-457.

10 W. K. Lai, P. J. Sun, J. Zhang, A. Jennings, P. F. Lalor, S. Hubscher, J. A. McKeating and D. H. Adams, Am. J. Pathol., 2006, 169, 200-208.

11 L. Tailleux, N. Pham-Thi, A. Bergeron-Lafaurie, J.-L. Herrmann, P. Charles, O. Schwartz, P. Scheinmann, P. H. Lagrange, J. de Blic, A. Tazi, B. Gicquel and O. Neyrolles, PLoS Med., 2005, 2, e381.

12 A. Domínguez-Soto, E. Sierra-Filardi, A. Puig-Kröger, B. Pérez-Maceda, F. Gómez-Aguado, M. T. Corcuera, P. Sánchez-Mateos and A. L. Corbí, J. Immunol., 2011, 186, 2192-2200.

13 B. J. Appelmelk, I. van Die, S. J. van Vliet, C. M. J. E. Vandenbroucke-Grauls, T. B. H. Geijtenbeek and Y. van Kooyk, J. Immunol., 2003, 170, 1635-1639.

14 Y. van Kooyk and T. B. H. Geijtenbeek, Nat. Rev. Immunol., 2003, 3, 697-709.

15 J. J. Garcia-Vallejo, N. Koning, M. Ambrosini, H. Kalay, I. Vuist, R. Sarrami-Forooshani, T. B. H. Geijtenbeek and Y. van Kooyk, Int. Immunol., 2013, 25, 221-233.

16 R. Ribeiro-Viana, M. Sánchez-Navarro, J. Luczkowiak, J. R. Koeppe, R. Delgado, J. Rojo and B. G. Davis, Nat. Commun., 2012, 3, 1-8.

17 F. Lasala, E. Arce, J. R. Otero, J. Rojo and R. Delgado, Antimicrob. Agents Chemother., 2003, 47, 3970-3972.

18 R. Ribeiro-Viana, J. J. García-Vallejo, D. Collado, E. PérezInestrosa, K. Bloem, Y. van Kooyk and J. Rojo, Biomacromolecules, 2012, 13, 3209-3219.

19 T. Kawaguchi, K. L. Walker, C. L. Wilkins and J. S. Moore, J. Am. Chem. Soc., 1995, 117, 2159-2165.

20 M. V. Walter and M. Malkoch, Chem. Soc. Rev., 2012, 41, 4593-4609.

21 W. Kowalczyk, A. Mascaraque, M. Sánchez-Navarro, J. Rojo and D. Andreu, Eur. J. Org. Chem., 2012, 4565-4573.

22 A. Nelson and J. F. Stoddart, Carbohydr. Res., 2004, 339, 2069-2075. 
23 For some representative glycodendron syntheses using TRIS as the branching core, see: (a) Y. M. Chabre, C. ContinoPépin, V. Placide, T. C. Shiao and R. Roy, J. Org. Chem., 2008, 73, 5602-5605; (b) R. Kaplánek, T. Bříza, M. Havlík, P. Martásek and V. Král, J. Fluorine Chem., 2007, 128, 179183; (c) P. R. Ashton, S. E. Boyd, C. L. Brown, N. Jayaraman, S. A. Nepogodiev and J. F. Stoddart, Chem.Eur. J., 1996, 2, 1115-1128.

24 C. Dupuy, R. Viguier and A. Dupraz, Synth. Commun., 2001, 31, 1307-1313.

25 G. R. Newkome and X. Lin, Macromolecules, 1991, 24, 14431444.
26 S. Munneke, J. C. Hill, M. S. M. Timmer and B. L. Stocker, Eur. J. Org. Chem., 2017, 3722-3728.

27 P. Edman, E. Högfeldt, L. G. Sillén and P.-O. Kinell, Acta Chem. Scand., 1950, 4, 283-293.

28 S. Munneke, G. Gainsford, G. F. Painter, B. L. Stocker and M. S. M. Timmer, Carbohydr. Res., 2015, 414, 1-7.

29 A. Puig-Kröger, D. Serrano-Gómez, E. Caparrós, A. Domínguez-Soto, M. Relloso, M. Colmenares, L. Martínez-Muñoz, N. Longo, N. Sánchez-Sánchez, M. Rincon, L. Rivas, P. Sánchez-Mateos, E. Fernández-Ruiz and A. L. Corbí, J. Biol. Chem., 2004, 279, 25680-25688. 